\title{
GENERASI Z SEBAGAI GENERASI WIRAUSAHA
}

\author{
Agung Purnomo1, Nur Asitah², Elsa Rosyidah², Andre Septianto2, \\ Margi Dwi Daryanti ${ }^{3}$, Mega Firdaus ${ }^{2}$ \\ ${ }^{1}$ Bina Nusantara University, Malang Campus \\ 2Universitas Nahdlatul Ulama Sidoarjo \\ ${ }^{3}$ Universitas Bahaudin Mudhary Madura \\ Email: agung.purnomo@binus.ac.id
}

\section{A. Generasi Z}

Generasi Z atau Gen Z atau iGen atau centennials, mengacu pada generasi yang lahir antara 1996-2010, setelah generasi milenium atau gen $Y$. Generasi Z telah dibesarkan oleh internet dan media sosial, sudah menjalani pendidikan tinggi di perguruan tinggi dan sebagian telah menyelesaikannya dan memasuki dunia kerja pada tahun 2020. Generasi Z tumbuh dengan teknologi, internet, dan media sosial, yang terkadang menyebabkan mereka mendapatkan stereotip sebagai pecandu teknologi, anti-sosial, atau pejuang keadilan sosial (Business Insider, 2019). Konteks itu telah menghasilkan generasi hiper kognitif yang sangat nyaman dengan mengumpulkan banyak referensi sumber informasi serta mengintegrasikan pengalaman virtual dan offline (Francis \& Hoefel, 2018).

\section{B. Generasi Wirausaha}

Dunia wirausaha menjadi trendi karena tampilan kesuksesan yang menyilaukan. Hal ini juga berimbas kepada generasi Z. Banyak Gen Z-ers memiliki preferensi untuk memulai bisnis mereka sendiri atau melakukan pekerjaan kontrak (Powers, 2018). Gen Z mempertimbangkan pilihan mereka dalam hal jalur karier yang andal sambil menghindari jebakan utang. Berbekal semangat kewirausahaan generasi milenial, tetapi dengan sedikit lebih hatihati dan pemikiran ke depan, Gen Z akan membuka jalan menuju kesuksesan tanpa mengikuti aturan orang lain. Sekitar $41 \%$ berencana untuk memulai wirausaha dan $45 \%$ percaya bahwa mereka dapat menemukan sesuatu yang merubah dunia (Online Schools Center, 2019). Generasi Z dalam suatu pekerjaan menekankan kepada hubungan sosial atas keseimbangan kerja dengan kehidupan dan pengalaman sehari-hari yang baik atas manfaat besar (Wallace, 2019). 


\section{Alasan Generasi Z Memilih Wirausaha}

Ada beberapa alasan mengapa generasi $Z$ lebih memilih jalur wirausaha dan bisnis alih-alih bekerja.

1. Tak mau dibatasi

Sebuah studi survei yang dilakukan oleh Universum Global terhadap 50.000 siswa kelompok Gen-Z menunjukkan bahwa 36\% dari Gen-Zers takut akan terjebak dalam karier yang tidak memungkinkan mereka mengembangkan peluang. Dengan kata lain, mereka tidak ingin didefinisikan atau dibatasi (Powers, 2018).

2. Kuliah bukan jaminan sukses

Hasil riset Universum Global juga memperlihatkan bahwa 56\% generasi $Z$ akan mempertimbangkan bergabung dengan tenaga kerja alih-alih kuliah. Artinya, semakin banyak Gen-Zers tidak melihat perguruan tinggi sebagai unsur penting untuk sukses. Ini karena generasi $Z$ telah belajar melalui teknologi digital, dan bukannya pembelajaran tradisional seperti pembelajaran kelas selama beberapa dekade terakhir. Generasi Z memiliki keyakinan bahwa mereka dapat belajar dari sumber-sumber non-tradisional dan berhasil (Powers, 2018).

3. Situs Layanan freelance dan peer-to-peer

Berkat situs-situs seperti Projects.co.id, sribulancer, freelance Indonesia, tidak pernah mudah seperti ini untuk memonetisasi keterampilan dan pengetahuan generasi $Z$ dan digital native. Remaja mengambil keuntungan penuh dari jaringan peer-to-peer. Banyak platform online dan seluler memungkinkan remaja untuk dengan mudah menemukan pekerjaan freelance dan terhubung dengan klien potensial (Paquette, 2019).

4. Media Sosial dimana-mana

Membuat dan mempromosikan konten kita sendiri semakin mudah berkat media sosial. YouTube, khususnya, telah menarik perhatian remaja inovatif yang ingin berbagi keahlian mereka dengan dunia. Hari ini, remaja dapat membuat saluran YouTube mereka sendiri, dan menulis, mengarahkan, memproduksi, membintangi, dan mempromosikan konten mereka sendiri, pada hampir semua subjek. Seperti yang digambarkan oleh kesuksesan vlogger kecantikan, publikasi media dan merek besar (Paquette, 2019).

5. Akses berlimpah

Gen $\mathrm{Z}$ beruntung memiliki situs web di mana mereka dapat mengajari diri mereka sendiri keterampilan baru yang memungkinkan mereka untuk menjadi pengusaha yang lebih baik. Selama beberapa tahun terakhir, kami telah menyaksikan maraknya kursus online terbuka besar. Di atas semua sumber daya itu, sekarang ada ribuan sumber daya tambahan yang gratis atau berbiaya rendah dan dijalankan oleh para ahli di situs-situs seperti Udemy dan SkillShare. Ada ratusan ribu buku yang diterbitkan setiap tahun dan karena Gen Z adalah pengguna tablet, ponsel dan komputer, menjadi 
lancar bagi mereka untuk mengakses saran dari pengusaha (Schawbel, 2014).

6. Mentor

Gen Z memiliki akses ke berbagai mentor di bidangnya. Banyak mentor akan senang berhubungan dengan siswa sekolah menengah yang berjiwa wirausaha. Mereka dapat terhubung dengan mereka dengan membaca blog mereka, tweet dengan mereka atau bahkan mengirim email secara langsung. Internet telah memberi mereka akses yang belum pernah terjadi sebelumnya pada usia yang begitu muda untuk berhubungan dengan mentor yang dapat membantu mereka membuat keputusan bisnis yang lebih baik. Mereka juga dapat memanfaatkan para ahli dengan mengunjungi situs, di mana mereka membayar sedikit biaya untuk melakukan sesi pelatihan selama satu jam dengan pengusaha sukses (Schawbel, 2014).

\section{Penutup}

Generasi Z yang tumbuh dengan teknologi, internet dan media sosial memiliki preferensi untuk memulai wirausaha. Beberapa alasan generasi Z memilih jalur wirausaha adalah tak mau dibatasi, kuliah bukan jaminan sukses, situs layanan freelance dan peer-to-peer, media sosial dimana-mana, akses berlimpah, dan mentor.

\section{Referensi}

Business Insider. (2019). Generation Z: Latest Characteristics, Research, and Facts.

Retrieved December 22, 2019, from

https://www.businessinsider.com/generation-z?IR=T

Francis, T., \& Hoefel, F. (2018). 'True Gen' : Generation Z and its implications for companies. Retrieved from https://www.mckinsey.com/industries/consumerpackaged-goods/our-insights/true-gen-generation-z-and-its-implications-forcompanies

Online Schools Center. (2019). Doing It Their Way: Gen Z And Entrepreneurship. Retrieved December 22, 2019, from https://www.onlineschoolscenter.com/genz-entrepreneurship/

Paquette, A. (2019). Gen Z is poised to become the most entrepreneurial generation ever-even more so than millennials. Retrieved December 22, 2019, from https://www.visioncritical.com/blog/entrepreneurial-gen-z

Powers, A. (2018). Why Gen-Z Talent Is More Likely To Pursue Entrepreneurship. Retrieved December 22, 2019, from https://www.forbes.com/sites/annapowers/2018/07/31/why-gen-z-talent-ismore-likely-to-pursue-entrepreneurship/\#69492b667822

Schawbel, D. (2014). Why "Gen Z" May Be More Entrepreneurial Than "Gen Y." Retrieved December 23, 2019, from https://www.entrepreneur.com/article/231048 
Wallace, B. (2019). Gen Z: The Entrepreneurial Generation. Retrieved December 22, 2019, from https://mystudentvoices.com/gen-z-the-entrepreneurialgeneration-1186ebc38829 